University of Nebraska - Lincoln

DigitalCommons@University of Nebraska - Lincoln

1962

PURIFICATION AND SANITARY CONTROL OF WATER (POTABLE AND WASTE)

Paul W. Kabler

Follow this and additional works at: https://digitalcommons.unl.edu/publichealthresources

Part of the Community Health and Preventive Medicine Commons, and the Environmental Public Health Commons

This Article is brought to you for free and open access by the Public Health Resources at DigitalCommons@University of Nebraska - Lincoln. It has been accepted for inclusion in Public Health Resources by an authorized administrator of DigitalCommons@University of Nebraska - Lincoln. 


\title{
PURIFICATION AND SANITARY CONTROL OF WATER (POTABLE AND WASTE) (i, $^{i}$
}

\author{
By Paul W. Kabler \\ Robert A. Taft Sanitary Engineering Center, \\ U. S. Public Health Service, \\ Cincinnati, Ohio
}

Although most of the streams draining inhabited regions are contaminated with human or animal feces, water-borne disease today in the United States is relatively uncommon. Pathogenic enteric microorganisms probably do not multiply in raw water sources under normal conditions. They usually disappear in a relatively short time, with the rates depending on variations in environmental conditions. Urban water supplies have played a diminishing role in the transmission of intestinal disease because of improvements in the detection and enumeration of pollution indicators, water and sewage treatment processes, and the sanitary control of water systems.

\section{Coliform Organisms}

In interpreting the significance of coliform densities or classifications by types and species described in the literature, careful consideration should be given to the methods used by the investigators; most of the coliform group densities reported before 1951, and many since, were based on the multiple tube procedure. This method yields a most probable number value, representing the density calculated on statistical expectations and is not an actual count of the viable bacteria present. Woodward (1) computed the 95 per cent confidence limit for a three-tube multiple decimal dilution test to extend over a 33-fold range from approximately 14 to 485 per cent of the true bacterial density. For a five-tube multiple dilution test, the 95 per cent confidence limits had a 13 -fold range from approximately 24 to 324 per cent. Bacterial enumeration

dia such as those containing agar and gelatin, or by a membrane filter technique, represent direct colony counts with expected variations of \pm 15 per cent. Classification by types or species of the coliform group where primary isolation was made from liquid medium may represent the most rapidly growing strains with suppression of other coliform types rather than the true percentage distribution in the original sample.

Fraser, Reid \& Malcolm (2) seldom found coliform bacteria on the foliage of a wide variety of garden plants, trees, shrubs, and field plants, including pastures, except where the possibility of contamination by insects, animals, or dust existed. Coliform bacteria were found on about one-third 1961.

${ }^{1}$ The survey of the literature pertaining to this review was concluded in December,

'The following abbreviation will be used: ECHO (enteric cytopathogenic human orphan). 
of the grains examined. Thomas \& Hobson (3) also found that aerogenescloacae strains and intermediate types of coli-aerogenes were normal bacterial flora of ears and panicles of growing cereals. In soil samples from sites exposed to animal contamination, E. coli type I predominated while a large number of soils from grassy banks, only remotely exposed to contamination, contained intermediates [Randall (4)]. Some species of animals, such as the coyote, bear, pocket gopher, and Columbian ground squirrel, had a coliform content that frequently approached that of the human [Drake, Woods \& Hammerstrom (5)]. However, rabbits, deer, elk, shrews, many birds, and almost half of the mice tested were reported to have very few or no coliform bacteria present in the quantities of feces tested. A series of $11 \mathrm{farm}$ water supplies examined by Thomas, Hobson \& Druce (6) showed a marked seasonal variation in the incidence of different coliform types isolated. In a year's study of two private wells, Voelker, Heukelekian \& Orford (7) observed that high coliform counts were typical of the warmer months, with densities decreasing through the fall to minimum values in January, followed by a steady increase through the spring.

Habs \& Langeloh (8) concluded that the presence of atypical E. coli indicated that unfiltered surface water had gained access to the water source and was grounds for rejection of the supply even though this indicator may not represent direct fecal pollution.

Christovao (9) proposed the use of a corrected coliform index which took into account the morbidity rate of typhoid fever in the community. According to Kichenko (10), all varieties of coliform bacteria can serve as indicators of fecal contamination of water. Kabler \& Clark (11) stated that the presence of any type of coliform organism in treated drinking water suggests either inadequate treatment or access of undesirable materials to the water after treatment. Insofar as bacterial pathogens are concerned, the coliform group is considered to be a reliable indicator of treatment adequacy. Whether these considerations can be extended to include rickettsial and viral organisms has not been definitely determined.

Slanetz \& Bartley (12) found that coliform densities obtained by the membrane filter technique were in good agreement with results obtained by the Standard Methods MPN procedure for samples of river and reservoir water. This new technique afforded considerable savings in time, materials, and labor. Geldreich et al. (13) described a delayed incubation coliform test on the membrane filter which yielded results comparable to the multiple tube dilution method. This procedure consisted of filtration of the sample at the collection site, placement of the membrane on a preservative medium, followed by unrefrigerated shipment to a laboratory for completion of the bacterial examination. Further developments, advantages, and limitations of membrane filter procedures for the determination of coliform organisms have been detailed by Rawn \& Bowerman (14), Clark et al. (15), Hazey (16), Burman (17), Fifield \& Schaufus (18), and McCarthy et al. (19). The Executive Committee of the American Water Works Association (20) 
accepted the membrane filter procedure as an alternate to the completed multiple tube dilution test by official action. The method is included in Standard Methods for the Examination of Water and Wastewater, 11th edition, 1960 (21).

\section{Fecal Coliforms}

Escherichia coli type I (IMViC ++--) has been traditionally considered to be of intestinal origin and, therefore, an indicator of fecal pollution. Other types of coliform organisms, with the possible exception of IMViC type -+-- , have been associated frequently with vegetation, soil, and other nonfecal sources, although occasionally recovered from human and animal excrement and from sewage-polluted waters. It has become increasingly evident, therefore, that the IMViC reactions do not satisfactorily differentiate coliforms of fecal and nonfecal origin, and the $E$. coli, as presently defined $(++--)$, is too restrictive because other types are found in appreciable numbers in the feces of humans and other warmblooded animals.

Numerous methods have been proposed for the accurate, rapid, and convenient detection and enumeration of fecal coliforms in potable water, stream samples, and sewage. In 1904, Eijkman proposed a "fecal coli" test that he believed differentiated between coliforms from the gut of warmblooded animals and strains originating from cold-blooded ones and typical soil coliforms. The method was based on the assumption that only fecal types of coliforms from warm-blooded animals could grow in glucose at $46^{\circ} \mathrm{C}$ with production of gas. Since that time, many investigators have explored the reliability of increased temperature incubation procedures for estimating fecal contamination.

Buttiaux et al. (22) and Papavassiliou (23) observed good agreement of gas production from lactose and indole formation at $44^{\circ} \mathrm{C}$ with $E$. coli type I cultures. However, there was no information given as to correlation of the fecal sources with the ability to grow at $44^{\circ} \mathrm{C}$. In a study of flora of stools from six normal individuals, Young et al. (24) showed that strains of $E$. coli varied and, on two occasions, pure cultures of Aerobacter aerogenes were grown from the fecal samples. Hendriksen (25) determined the frequency of the different coliform types (IMViC and $44^{\circ} \mathrm{C}$ tests) in feces and water in Norway. Although he isolated various coliform types in addition to $E$. coli type I from feces, he apparently did not consider these types of fecal origin when isolated from water. Levine et al. (26) considered gas production from boric acid lactose broth at $43^{\circ} \mathrm{C}$ for $48 \mathrm{hr}$ to be a reliable criterion for the probable presence of $E$. coli, as only 0.7 per cent of intermediate coliforms, and 5 per cent of $A$. aerogenes strains produced gas under these conditions. He implied that the presence of " $E$. coli" by this test was indicative of fecal pollution. Clark et al. (27) reported the growth reaction of 4423 coliform strains isolated from surface waters in boric acid lactose broth as compared to their IMViC characteristics. In this study, 20.1 per cent of $A$. aerogenes $(--++)$; 81.1 per cent of intermediate +++- , 
and appreciable numbers of other intermediate coliform strains produced gas in the BALB test. The sanitary significance of these findings was not determined. In a study of 5794 coliform cultures from raw water sources, Geldreich et al. (28) again found that significant numbers of IMViC types ,+++--++ , and other intermediates produced gas in EC medium in $24 \mathrm{hr}$ at $45^{\circ} \mathrm{C}$. These results suggested that additional efforts should be made to locate sources of fecal pollution of waters containing EC-positive coliforms. This position was supported by Keller (29) in South Africa, who considered the presence of gas-producing bacteria in MacConkey broth at $44.5^{\circ} \mathrm{C}$ for $48 \mathrm{hr}$ to be a good indicator of pollution. By designating these organisms as $E$. coli, he introduced a conflict in terminology. Evidence is accumulating that incubation at increased temperatures $\left(44^{\circ}\right.$ to $\left.45^{\circ} \mathrm{C}\right)$ perhaps more accurately enumerates those coliforms of fecal origin than does the IMViC system of classification. For this reason, it is suggested that the term "fecal coliforms" be used to designate the group.

\section{Fecal Streptococci}

Streptococci have been recognized as important components of fecal material since the turn of the century. Their slow acceptance as indicators of pollution has resulted from the multiplicity and difficulty of laboratory procedures, poor agreement between methods of quantitative enumeration, and lack of systematic studies of the sources, survival, and interpretation of streptococci in various types of environment. Undue attention has been given the Streptococcus fecalis group (enterococci) with little regard for other streptococcal strains present in the gut of humans and other warmblooded animals and birds.

Following the description of a new azide medium by Litsky, Mallmann \& Fifield in 1953 (30), the detection and enumeration of fecal streptococci have received increasing interest. Tube dilution methods using this medium were much simpler and more specific for streptococci. Slanetz \& Bartley (31) introduced a modified medium for use with the membrane filter which enumerated other fecal strains in addition to the species designated as "enterococci." Using this procedure, Sullivan et al. (32) found that streptococci occurred in the feces of man and certain animals, and in polluted water and sewage, in as great or even greater numbers than did coliform bacteria. In certain instances, it was believed possible to distinguish between human and animal sources of bacterial contamination of water by the types of streptococci present in the sample. In 1959, Spaander \& Roest (33) discussed "the detection of fecal streptococci in drinking water." Guthof \& Dammann (34) observed comparable streptococcus and coli titers in water samples from springs and from the Rhine River. They recommended adoption of the streptococcal test as a worthwhile addition to routine bacteriological examination of water. In the examination of 369 undisturbed soil samples from areas in which fecal contamination was reported to be nonexistent or a very remote possibility, Medrek \& Litsky (35) found 
comparably low distributions of streptococci and $E$. coli, but much higher coliform content. The authors state that when the factors of expedience and economy of materials are considered, the use of the streptococcal group as the preferred index of pollution seems justified.

Kenner et al. (36) described a modified medium for membrane filter and agar plate count techniques which propagated a larger number of fecal streptococcal types from human and animal feces and polluted environments. The medium did not support the growth of $S$. cremoris, S. lactis, S. pyogenes, and $S$. thermophilus, or such organisms as Pedicoccus cerevisiae, Leuconostoc mesenteroides, and Lactobacillus. Using this medium, the authors (37) found that the average number of streptococci discharged in a 24-hr period increased in the source order of humans, fowl, cow, sheep, and pig. The enterococcus group predominated in human feces to account for 93 per cent of the streptococcal population; the quadrupeds showed appreciable quantities of the $S$. bovis and $S$. equinas groups, which were approximately 75 per cent for cow, 46 per cent for sheep, and 56 per cent for the pig. A careful classification of the streptococcal groups permitted a qualitative interpretation of the source of pollution. The "fecal streptococci" include the enterococcus group, $S$. bovis group, $S$. equinas group, and an atypical group closely resembling the enterococci. Bartley \& Slanetz (38) also determined the streptococcal content of feces from humans and domestic animals. Their findings indicate that while typical $S$. fecalis may not always be the predominant type of streptococcus in human feces, it is far less prevalent in the feces of most domestic animals. Thus, its presence in water would indicate contamination of human origin. The presence of $S$. bovis in a water sample would indicate recent bovine or ovine pollution.

Kjellander (39) showed that $S$. fecalis comprised 46 per cent of the streptococci in human feces and only 2 to 9 per cent in domestic animals. Forty-nine per cent of the streptococci derived from humans fermented sorbitol, and 6 to 15 per cent from animals exhibited the same characteristic. He concluded that the presence of sorbitol-fermenting streptococci indicated human pollution. When sewage was diluted with well water and stored at $5^{\circ} \mathrm{C}$ for 5 days, $E$. coli showed the greatest decrease in numbers. The numbers of coliforms and streptococci decreased at about the same rate. Similar survivals were observed when sewage was diluted with river water and stored at $1^{\circ} \mathrm{C}$. After 18 days storage, the population of all three groups was decreased 99 per cent or more. In surveys of river pollution, Keller (29) considered the presence of streptococci to be a good index of pollution. Streptococci survived longer than of "delayed" pollution when E. coli are absent or present in small numbers.

Sufficient data have been accumulated to justify further investigations in the distribution and persistence of the fecal streptococci to support sanitary interpretations of pollution. The nomenclature and classification of the group still present many problems. This is chiefly the result of the many variations which occur in the biochemical characteristics of the different 
strains, and it is difficult to determine which should be assigned species, variety, or biotype status. It seems desirable to designate this group of organisms as "fecal streptococci."

\section{ENTERIC Viruses}

The term "enteric virus" as used here, includes all viruses which are found in quantity in human feces and in sewage. They have been classified into subgroups as: infectious hepatitis, Coxsackie A and B, poliovirus, adenovirus, and ECHO. Many years ago, Toomey et al. (40) isolated a polio-like virus from creek waters in Ohio by direct transmission to a cotton rat, and Kling (41), in Sweden, demonstrated poliovirus in well water. More recently, an unclassified adenovirus was recovered from a water sample taken from an ejector-type drinking fountain at a boys' camp [Paffenbarger et al. (42)], and enteroviruses were isolated from Hudson River water 400 feet down river from the Albany sewage plant outfall, by Kelly \& Sanderson (43).

Although the enteroviruses rarely have been demonstrated in raw surface waters or in treated supplies, they have been readily isolated from domestic sewage and all stages of sewage treatment plant effluent tested, including the final effluent. Kelly \& Sanderson $(43,44)$ found 2 to 44 plaqueforming units of viruses per $100 \mathrm{ml}$ of raw sewage and identified 15 strains of Coxsackie, ECHO, and polioviruses. The highest densities were found in August and early September, and larger numbers of viruses occurred in samples of raw sewage than in treated sewage. Of 150 viruses isolated from sewage samples by Bloom et al. $(45,46), 31$ were identified as ECHO viruses, 3 as polioviruses, and 76 as Coxsackie viruses; 17 were not identified and 22 were lost. In 24 consecutive months, viruses were isolated in 8 per cent of 1403 tests. During a poliomyelitis epidemic in Des Moines, enteroviruses were isolated from 52.6 per cent of 108 sewage samples collected by the gauze-pad technique [Gravelle \& Chin (47)].

Clarke et al. (48) found that Coxsackie A2 virus survived 61 days in sewage at $8^{\circ} \mathrm{C}$ and 41 days when stored at $20^{\circ} \mathrm{C}$ in the laboratory. In distilled water at $8^{\circ} \mathrm{C}$, the virus survived more than 272 days, and at $20^{\circ} \mathrm{C}$, 41 days. In raw Ohio River water at $8^{\circ} \mathrm{C}$, it survived 16 days, and at $20^{\circ} \mathrm{C}$, only 6 days. In autoclaved Ohio River water, the survival times were more than 171 days and 102 days at $8^{\circ} \mathrm{C}$ and $20^{\circ} \mathrm{C}$, respectively. In water stored at $8^{\circ} \mathrm{C}$ to $10^{\circ} \mathrm{C}$, Coxsackie A5 virus survived 280 days [Gilcreas \& Kelly (49)]. Rhodes et al. (50) demonstrated poliovirus in experimentally contaminated river water after 188 days storage. According to Neefe et al. (51), the ability of stored contaminated well water to infect human volunteers with infectious hepatitis indicated that the virus was capable of at least 10 weeks survival. It appears that, in general, virus survival is longer in treated or clean waters than in polluted waters.

The removal of viruses from water by chemical flocculation appears to be a function of a cation-protein reaction in which a metal-virus com- 
plex is formed and aggregates into precipitates [Chang et al. (52, 53)]. Since the reaction is nonspecific, the procedure should be applicable to animal viruses in general. However, the degree of virus removal depends on the efficiency of the flocculation process which, when satisfactorily applied using 15 to $25 \mathrm{ppm}$ of either alum or ferric salt, can remove 95 to 99 per cent of Coxsackie A2 virus from water in a single-stage flocculation or more than 99 per cent in a double-stage operation. The removal efficiency may be slightly lower in the cold than in the warmer months. The virus removal roughly parallels the removal of coliform organisms, total bacteria, and turbidity.

\section{Water-Borne Virus Disease}

Infectious hepatitis is currently the only viral disease of humans for which the water-borne route of infection has been generally accepted, although it is believed that person-to-person contact is the more frequent method of transmission. It is difficult to establish the water-borne route of an infection, which may account for more cases than can be demonstrated by available methods. Neefe \& Stokes (54) are the only investigators who have demonstrated the infectious agent in water. Of 28 water-borne infectious hepatitis outbreaks reviewed by Mosley (55), 6 occurred in towns or cities served by a municipal water system. Five outbreaks were in villages and one was in a rural area having only multiple private supplies. The remaining 16 epidemics included groups exposed to private supplies serving institutions, industrial plants, resort hotels, or summer camps. Other outbreaks of water-borne infectious hepatitis attributed to chlorinated supplies were reported by Mosley et al. (56) and by Poskanzer \& Beadenkopf (57). Vogt (58) described an outbreak caused by contamination of the ground water aquifer by septic tank effluent through fractures in the limestone overlay. The largest reported waterborne epidemic occurred in New Delhi, India [Viswanathan (59)] following heavy sewage contamination of the raw water source. The fact that the epidemic occurred in spite of the extra precautions taken by the waterworks authorities by way of alum precipitation and superchlorination showed that the virus was not completely inactivated by such measures. The reliability of the coliform test to indicate the sanitary status in relation to viruses is currently undetermined. The presence of coliform organisms does not establish human fecal contamination, nor the presence of viruses. A negative coliform test does not necessarily exclude the presence of viruses.

Most poliomyelitis infections do not appear to be related to water transmission. However, Clarke \& Chang (60) reviewed two outbreaks that exhibited characteristics of water-borne disease. One outbreak occurred in Edmonton, Canada [Little (61)] and, from epidemiological evidence, was attributed to contaminated water from the Saskatchewan River. The other epidemic, in Nebraska, was investigated by Bankroft et al. (62). 
The epidemiological evidence pointed to sewage contamination of the water distribution system by back siphonage as the probable source of infection.

To date, no Coxsackie or ECHO viruses have been associated with water-borne disease. Because these viruses are excreted in feces and are readily isolated from raw sewage and treated effluents, they must be considered potential water-borne agents.

\section{Waste Treatment}

Microbial metabolism is the basic mechanism in the natural purification of polluted waters. Purification of such waters by engineered biological treatment processes, i.e., activated sludge, trickling filters, or oxidation ponds is, in this respect, not essentially different from natural stream self-purification [Ettinger (63)]. These processes are accomplished by the combined activities of numerous microbial species and variants. The contributing members of the biological system are dependent on the physical and chemical composition of the menstruum and have been selected and adapted from the infinite number of microorganisms and microenvironments in nature [Kabler (64)]. The ecology of bacteria in polluted fresh water, the succession of forms and the responses to oxygen and food supplies have been discussed by Heukelekian (65). The transformations of carbon compounds by microorganisms were excellently reviewed by Nickerson (66) who pointed out the common pathways of oxidations for carbohydrates, alcohols, acids, fats, waxes, and aromatic ring compounds. Delwicke (67) showed that the degradation of nitrogen compounds would invariably be accomplished by hydrolysis of proteins or other complex nitrogen molecules and would result in the eventual decomposition of the lower molecular weight residues. Diverse microorganisms participate in degradation of sulfur compounds, many of which command attention as they produce materials having objectionable odors or cause corrosion of industrial equipment [Starkey (68)]. The two principal sulfur products formed are sulfate under aerobic conditions and sulfide under anaerobic conditions.

Engelbrecht \& McKinney (69) studied acclimated activated sludge cultures developed on pure organic compounds. They concluded that activated sludges developed on strictly related chemical compounds had similar morphological appearances and produced similar biochemical changes. The chemical structure of the organic matter fed to activated sludge was found to be the controlling factor in the predomination of microorganisms and in the biochemical changes when all environmental factors were constant. When cultures showed similar biochemical changes, the most efficient organisms predominated and these in turn were determined by the metabolic pathway through which the compound was attacked. Activated sludge systems must have sufficient nitrogen supplied to satisfy the high synthesis demand occurring at the start of each aeration period [Symons \& 
McKinney (70)]. The nitrogen incorporated into the sludge during synthesis will be largely lost to the system when the sludge is degraded later in the aeration period. Symons et al. (71) found that the form, position, and number of nitrogen groups had an important influence on the ease of biological degradation of an organic compound containing nitrogen. The mechanism by which the nitrogen was removed from the organic molecule was the same regardless of the original form of the nitrogen. Care must be exercised in the interpretation of results from Stanier's method of simultaneous adaptation because of problems with nitrification, toxicity, and chemical reactivity of the suspected intermediates. Malaney (72) was able to train a "normal" activated sludge to utilize aniline (aminobenzene) as its sole source of carbon and energy. This acclimated sludge possessed the capacity to oxidize a wide variety of chemical compounds related in chemical structure to aniline. Feeding raw sludge heavily contaminated with copper or zinc to an active digester not previously acclimated may stop gas production for a considerable period [O'Neill (73)].

Ludzack \& Ettinger (74) have shown that the microbial populations of surface waters are readily acclimated to the degradation of hexadecanol. Biological destruction of a hexadecanol monolayer resulted in measurable consumption of the material with all substrates tested. The rate of oxidation varied with the type of substrate, the variety and kinds of organisms, and the age of the oxidation system.

Biological treatment by trickling filters, activated sludge, anaerobic digestion, or stabilization ponds will markedly reduce the numbers of pathogenic enteric bacteria, viruses, parasites, and tubercle bacilli in sewage, but the resulting effluents will contain some of each kind of microorganism present in the raw sewage [Kabler (75)]. The percentage removals vary with kind of microorganism as well as with type and efficiency of treatment process. Appropriate chlorination procedures, chemical flocculation with sedimentation, and heat treatment further reduce microbial populations. Keller (76) reported that sewage treatment in grass plots and maturation ponds reduced the numbers of coliform organisms more than 99 per cent.

Using a laboratory model activated sludge unit, Clarke et al. (77) removed approximately 90 per cent of type I poliovirus and about 98 per cent of Coxsackie A9 virus from a sewage suspension. Since the mechanism of removal of virus appeared to be an adsorption phenomenon, it was reasonable to infer that other enteric viruses would also be removed from sewage by such treatment. Only a small per cent of the virus was recovered, indicating that the sludge-virus complex was extremely stable or that most of the virus was in some manner inactivated. Coliform and fecal streptococci removals averaged about 97 and 96 per cent, respectively. Kelly et al. (78) used a fill-and-draw activated sludge unit to determine the removals of type I poliovirus and Coxsackie B5 from sewage. Over a 30-day period the range of removals was 94 to 99 per cent. Viruses were 
inactivated during the removal process, and the isolation of at least four strains of bacteria with antiviral activity suggested that biological antagonism was implicated.

Surface films on trickling filters receiving a continuous flow of sewage appeared to have a definite structure [Cooke \& Hirsch (79)]. Underlying the mat and at least partially embedded in the interstices of the rocks, was a layer of fungus mycelium, bacterial cells, algal cells, and protozoa, including sessile-stalked species attached to the stone. From this basic layer arose a mass of tissue including fungal and algal filaments, clusters of fungi, algae, and bacteria, and free-swimming protozoa and nematodes. Overlying all was another layer of fungus cells through which algae rarely penetrated but in which yeasts, bacteria and protozoa teemed. Höhnl (80) described the growths of Sphaerotilus natans and its numerous variants which predominate in paper mill effluents. $S$. natans required only minute amounts of nutrients; however, the organism failed to reproduce when oxygen dropped below $3 \mathrm{mg} / \mathrm{liter}$ or when the salinity exceeded 0.2 per cent.

\section{DisinfeCtion}

In a review of water disinfection practices, Laubusch $(81,82)$ noted that chlorinated lime was first used in the United States for water disinfection in 1908, liquid chlorine in 1912, and high-test hypochlorite in 1928. Disinfection and other treatment of wastes, sanitary and industrial, can prove most complex as regards the chemical reactions which occur. Christian et al. (83) have described an apparatus and procedure for measuring the disinfecting action over short intervals $(0.1 \mathrm{sec})$ of high chlorine residuals. The equipment and process were readily adaptable to the study of other disinfectants, enzyme reactions, and a variety of biochemical and physiological processes. McCarthy (84) found that a given amount of chlorine, properly mixed with sulfamic acid, gave greater kills of bacteria than the same amount of chlorine alone or as chloramine. Loss of active chlorine resulting from sunlight and wind and casual organic matter, was definitely reduced.

Clarke et al. (85) observed that purified type 3 adenovirus was readily inactivated by chlorine. The amounts required were approximately those needed to kill $E$. coli or $S$. typhosa. Kelly \& Sanderson $(86,87,88)$ reported that the viricidal efficiency of chlorine was dependent on $\mathrm{pH}$, chlorine concentration, exposure time, and temperature. The differences in the resistance of viruses to free chlorine were between strains rather than types. The strains, in the order of decreasing sensitivity, were Coxsackie B5, type I poliovirus (Mahoney), type II poliovirus, Coxsackie B1, type III poliovirus, and type I poliovirus ( $\mathrm{MK} 500$ ). At $25^{\circ} \mathrm{C}$ and a $\mathrm{pH}$ of 7.0 , a concentration of at least $9 \mathrm{ppm}$ of combined chlorine was necessary for the inactivation of poliovirus with a contact period of $30 \mathrm{~min}$, and of $6 \mathrm{ppm}$ with a 1-hr contact time. Weidenkopf (89), working with a "demand free" system of type I poliovirus, obtained very accurate quantita- 
tive results which indicated a first-order reaction in the destruction at $\mathrm{pH}$ 8.5 by free chlorine concentrations ranging from 0.2 to $5.0 \mathrm{ppm}$. Different types of enteric viruses varied widely in their degree of resistance to chlorine [Kabler et al. (90)]. Poliovirus, Coxsackie, and some ECHO viruses seemed to be more resistant than coliforms or enteric pathogenic bacteria. Combined chlorine was considerably less viricidal than free chlorine, requiring higher concentrations or longer contact periods to achieve comparable inactivation.

Inactivation of Clostridium botulinum toxins by free available chlorine occurred as long as a residual of free chlorine remained in the water [Brazis et al. (91)]. Lowering the temperature from $25^{\circ} \mathrm{C}$ to $5^{\circ} \mathrm{C}$ approximately tripled the time required for 99.90 to 99.99 per cent destruction of the toxins. Chloramines were relatively ineffective in destroying botulinum toxins. In a laboratory comparison, Watkins et al. (92) found hypochlorite relatively more effective than quaternary and iodophor germicides in destroying lactic streptococcus bacteriophage.

In a study of used water during pea and corn canning operations, Welch \& Folinazzo (93) observed that treatment of the used water with chlorine dioxide was more effective in maintaining sanitary conditions than in-plant chlorination alone or in-plant chlorination plus rechlorination. Water containing $20 \mu \mathrm{g} / \mathrm{liter}$ of phenol was treated satisfactorily by Wideman (94) with chlorine dioxide. Heavy bacterial pollution was completely removed within one minute by the addition of $0.06 \mathrm{mg} / \mathrm{liter}$ of chlorine dioxide; $0.12 \mathrm{mg} / \mathrm{liter}$ of chlorine achieved the same effect only after 20 minutes.

Johannesson $(95,96)$ found that the rate of destruction of bacteria by monobromamine was proportional to the concentration of the monobromamine ion. At neutral $\mathrm{pH}$ values the action of monobromamine on bacteria was rapid. The bactericidal properties of monobromamine were almost equal to those of free bromine which are similar to those of chlorine.

Wetzler (97) discussed the broad applications of iodine in water disinfection. He believed that the old conventional microorganisms of reference standards have been largely supplanted by more resistant forms, such as cysts of Endamoeba histolytica. Iodine was most efficient in acid medium, so that excessively alkaline waters might require $\mathrm{pH}$ adjustment to a level of $\mathrm{pH} 7.2$ to 7.6 before dosage. Chang (98) evaluated the use of active iodine as a water disinfectant and cited equations for computing the various species of titrable iodine in aqueous solutions of elemental iodine and iodide. The relative cysticidal and viricidal efficiencies of the various titrable iodine species were compared. Because viruses are more resistant than amoeba cysts, the iodine dosage should be based on virus rather than cyst destruction to give a greater margin of safety.

Hann (99) reviewed the European and American experiences of using ozone as a water disinfectant. Ozone compared favorably with chlorine. When iron or manganese content of the water exceeded $0.2 \mathrm{ppm}$, ozone 
treatment had to be followed by filtration to remove the precipitates. According to Stumm (100), the "ozone demand" of natural water was generally larger than the corresponding chlorine demand, and the ozone demand of sewage may be exorbitant. Ozonation proved effective in removal of materials causing taste and odor, particularly the phenolics in the Schuylkill River [Bean (101)]. Ozone concentrations of 0.16 to $0.20 \mathrm{ppm}$ killed approximately 98 per cent of coliform organisms and other bacteria which grew at $37^{\circ} \mathrm{C}$ on a nutrient agar medium.

Chambers \& Proctor (102) found that the germicidal action of a specified amount of silver was related to the concentration of silver ions rather than to the physical nature of the silver from which the ions were originally derived. Phosphate tended to decrease the germicidal efficiency, while increases of $\mathrm{pH}$ were accompanied by accelerated death rates. In the absence of efficient neutralizers, bacteriostasis may be mistaken for bactericidal action. Wuhrmann \& Zobrist (103) considered the effects of temperature, $\mathrm{pH}$ and silver concentration to be independent of each other, and to exert strong influences on the bactericidal action of silver. The presence of $0.01 M$ phosphate and of calcium in concentrations found in drinking water interfered with the bactericidal action.

\section{LITERATURE CITED}

1. Woodward, R. L., J. Am. Water Works Assoc., 49, 1068 (1957)

2. Fraser, M. H., Reid, W. B., and Malcolm, J. F., J. Appl. Bacteriol., 19, 301 (1956)

3. Thomas, S. B., and Hobson, P. M., J. Appl. Bacteriol., 18, 1 (1955)

4. Randall, J. S., J. Hyg., 54, 365 (1956)

5. Drake, C. H., Woods, F. W., and Hammerstrom, R. A., The Sanitarian, 23, 248 (1961)

6. Thomas, S. B., Hobson, P. M., and Druce, R. G., J. Appl. Bacteriol., 22, 32 (1959)

7. Voelker, R. A., Heukelekian, H., and Orford, H. E., Am. J. Public Health, 50, 1873 (1960)

8. Habs, H., and Langeloh, H., Arch. Hyg. u. Bakteriol., 142, 401 (1958)

9. Christovao, D. A., Arquiv. fac. hig. e saúde pública univ. Sảo Paulo, 11, 89 (1957)

10. Kichenko, M. G., J. Microbiol., Epidemiol., Immunobiol., 28, 62 (1957)

11. Kabler, P. W., and Clark, H. F., J. Am. Water Works Assoc., 52, 1577 (1960)

12. Slanetz, L. W., and Bartley, C. H., Appl. Microbiol., 3, 46 (1955)
13. Geldreich, E. E., Kabler, P. W., Jeter, H. L., and Clark, H. F., Am. J. Public Health, 45, 1462 (1955)

14. Rawn, A. M., and Bowerman, F. R., Water \& Sewage Works, 103, 36 (1956)

15. Clark, H. F., Kabler, P. W., and Geldreich, E. E., Water \& Sewage Works, 104, 385 (1957)

16. Hazey, G., Am. City, 73, 116 (1958)

17. Burman, N. P., Proc. Soc. Water Treatment \& Exam., 9, 60 (1960)

18. Fifield, C. W., and Schaufus, C. P., J. Am. Water Work Assoc., 50, 193 (1958)

19. McCarthy, J. A., Delaney, J. E., and Grasso, R. J., Water \& Sewage Works, 108, 238 (1961)

20. Annon., J. Am. Water Works Assoc., 50, 72 (1958)

21. Standard Methods for the Examination of Water and Wastewater, 11 th ed., 508-13 (Am. Pub. Health Assoc., New York, N.Y., 626 pp., 1960)

22. Buttiaux, R., Samaille, J., and Pierens, Y., Ann. inst. Pasteur, 8, 137 (1956)

23. Papavassiliou, J., J. Appl. Bacteriol., 21, 104 (1958)

24. Young, V. M., Gillem, H. C., Massey, 
E. D., and Branche. W. C., Jr., Bacteriol. Proc. (Soc. Am. Bacteriologists), 60, 134 (1960)

25. Hendriksen, S. D., Acta. Pathol. Microbiol. Scand., 35, 75 1954)

26. Levine, M., Tanimoto, R. H., Minette, H., and Arakaki, J., $A p p l$. Microbiol., 3, 310 (1955)

27. Clark, H. F., Geldreich, E. E., Kabler, P. W., Bordner, R. H., and Huff, C. B., Appl. Microbiol., 5, 396 1957)

28. Geldreich, E. E., Clark, H. F., Kabler, P. W., Huff, C. B., and Bordner, R. H., Appl. Microbiol., 6, 347 (1958)

29. Keller, P., Hydrobiologia (S. Africa), 14, 205 (1960)

30. Litsky, W., Mallmann, W. L., and Fifield, C. W., Am. J. Public Health, 43, 473 (1953)

31. Slanetz, L. W., and Bartley, C. H., J. Bacteriol., 74, 591 1957)

32. Sullivan, M., Bartley, C. H., and Slanetz, L. W., Am. J. Public Health, 47, 618 (1957)

33. Spaander, P., and Roest, A. C. F., Antonie van Leeurvenhoek $J_{\text {. }}$ Microbiol. Serol., 25, 169 (1959)

34. Guthof, O., and Dammann, G., Arch. Hyg. u. Bakteriol., 142, 559 (1958)

35. Medrek, T. F., and Litsky, W., Appl. Microbiol., 8, 60 (1960)

36. Kenner, B. A., Clark, H. F., and Kabler, P. W., Appl. Microbiol., 9, 15 (1961)

37. Kenner, B. A., Clark, H. F., and Kabler, P. W., Am. J. Public Health, 50, 1553 (1960)

38. Bartley, C. H., and Slanetz, L. W., Am. J. Public Health, 50, 1545 (1960)

39. Kjellander, J., Acta. Pathol. Microbiol. Scand., 48, 9 (1960)

40. Toomey, J. A., Takas, W. S., and Weaver, H. M., Am. J. Diseases Children, 70, 293 (1945)

41. Kling, C., Intern., Bull. Econ. M. Research and Public Health, [A]40, 161 (1939-40)

42. Paffenbarger, R. S., Berg, G., Clarke, N. A., Stevenson, R. E., Pooler, B. G., and Hyde, R. T., Am. J. Hyg., 70, 254 (1959)

43. Kelly, S., and Sanderson, W. W., Sewage and Ind. Wastes, 31, 683 (1959)

44. Kelly, S., and Sanderson, W. W., J. Water Polution Cont. Fed., 32, 1269 (1960)
45. Mack, W. N., Mallmann, W. L., Bloom, H. H., and Krueger, B. J., Sewage and Ind. Wastes, 30, 957 (1958)

46. Bloom, H. H., Mack, W. N., Krueger, B. J., and Mallmann, W. L., $J$. Infectious Diseases, 105, 61 (1959)

47. Gravelle, C. R., and Chin, T. D., J. Infectious Diseases, 109, 205 (1961)

48. Clarke, N. A., Stevenson, R. E., and Kabler, P. W., J. Am. Water Works Assoc., 48, 677 (1956)

49. Gilcreas, F. W., and Kelly, S. M., J. Am. Water Works Assoc., 47, 683 (1955)

50. Rhodes, A. J., Clark, E. M., Knowles, D. S., and Goodfellow, A. M., Can. J. Public Health, 41, 146 (1950)

51. Neefe, J. R., Stokes, J., Jr., Baty, J. B., and Reinhold, J. G., J. Am. Med. Assoc., 128, 1076 (1945)

52. Chang, S. L., Stevenson, R. E., Bryant, A. R., Woodward, R. L., and Kabler, P. W., Am. J. Public Health, 48, 51 (1958)

53. Chang, S. L., Stevenson, R. E., Bryant, A. R., Woodward, R. L., and Kabler, P. W., Am. J. Public Health, 48, 159 (1958)

54. Neefe, J. R., and Stokes, J., Jr., J. Am. Med. Assoc., 128, 1063 (1945)

55. Mosley, J. W., New Engl. J. Med., 261, 703 (1959)

56. Mosley, J. W., Schrack, W. D., Jr., Matter, L. D., and Densham, T. W., Am. J. Med., 26, 555 (1959)

57. Poskanzer, D. C., and Beadenkopf, W. G., Public Health Repts. (U.S.), 76, 745 (1961)

58. Vogt, J. E., J. Am. Water Works Assoc., 53, 1238 (1961)

59. Viswanathan, R., Indian J. Med. Research, 45, 1 (1957)

60. Clarke, N. A., and Chang, S. L., J. Am. Water Works Assoc., 51, 1299 (1959)

61. Little, G. M., Can. J. Public Health, 45, 100 (1954)

62. Bankroft, P. M., Engelhard, W. E., and Evans, C. A., J. Am. Med. Assoc., 164, 836 (1957)

63. Ettinger, M. B., Sewage and Ind. Wastes, 30, 14 (1958)

64. Kabler, P. W., Am. J. Public Health, 50, 215 (1960) 
65. Heukelekian, H., Tappi, 43, 196A (1960)

66. Nickerson, W. J., Ind. Eng. Chem., 48, 1411 (1956)

67. Delwicke, C. C., Ind. Eng. Chem., 48, 1421 (1956)

68. Starkey, R. L., Ind. Eng. Chem., 48, 1429 (1956)

69. Engelbrecht, R. S., and McKinney, $\mathrm{R}$. E., Servage and Ind. Wastes, 29, 1350 (1957)

70. Symons, J. M., and McKinney, R. E., Sewage and Ind. Wastes, 30, 874 (1958)

71. Symons, J. M., McKinney, R. E., Smith, R. M., and Donovan, E. J., Jr., Intern. J. Air and Water Pollution, 4, 115 (1961)

72. Malaney, G. W., J. Water Polution Cont. Fed., 32, 1300 (1960)

73. O'Neill, J., J. and Proc. Inst. Sewage Purification, Pt. 2, 150 (1957)

74. Ludzack, F. J., and Ettinger, M. B., J. Am. Water Works Assoc., 49, 849 (1957)

75. Kabler, P. W., Sewage and Ind. Wastes, 31, 1373 (1959)

76. Keller, P., J. Hyg., 57, 410 (1959)

77. Clarke, N. A., Stevenson, R. E., Chang, S. L., and Kabler, P. W., Am. J. Public Health, 51, 1118 (1961)

78. Kelly, S., Sanderson, W. W., and Neidl, C., J. Water Polution Cont. Fed., 33, 1056 (1961)

79. Cooke, W. B., and Hirsch, A., Sewage and Ind. Wastes, 30, 138 (1958)

80. Höhnl, W., Wochbl. Papierfabrik., 84, 564 (1956)

81. Laubusch, E. J., J. Am. Water Works Assoc., 52, 1416 (1960)

82. Laubusch, E. J., Water \& Sewage Works, 107, 443 (1960)

83. Christian, E. D., Barada, M. F., and Renn, C. E., J. Am. Water Works Assoc., 53, 307 (1961)

84. McCarthy, J. A., J. New Engl. Water Works Assoc., 74, 166 (1960)
85. Clarke, N. A., Stevenson, R. E., and Kabler, P. W., Am. J. Hyg., 64, 314 (1956)

86. Kelly, S., and Sanderson, W. W., Science, 126, 560 (1957)

87. Kelly, S., and Sanderson, W. W., Am. J. Public Health, 48, 1323 (1958)

88. Kelly, S., and Sanderson, W. W., Am. J. Public Health, 50, 14 (1960)

89. Weidenkopf, S. J., Virology, 5, 56 (1958)

90. Kabler, P. W., Clarke, N. A., Berg, G., and Chang, S. L., Public Health Repts. (U.S.), 76, 565 (1961)

91. Brazis, A. R., Bryant, A. R., Leslie, J. E., Woodward, R. L., and Kabler, P. W., J. Am. Water Works Assoc., 51, 902 (1959)

92. Watkins, S. H., Hays, H., and E1liker, P. R., J. Milk and Food Technol., 20, 84 (1957)

93. Welch, J. L., and Folinazzo, J. F., Food Technol., 13, 179 (1959)

94. Wideman, O., Vom Wasser, 24, 50 (1957)

95. Johannesson, J. K., New Zealand J. Sci., 2, 499 (1959)

96. Johannesson, J. K., Am. J. Public Health, 50, 1731 (1960)

97. Wetzler, T. F., Soap Chem. Specialties, 35, 115 (1959)

98. Chang, S. L., J. Am. Pharm. Assoc., 47, 417 (1958)

99. Hann, V. A., J. Am. Water Works Assoc., 48, 1316 (1956)

100. Stumm, W., J. Boston Soc. Civil Engrs., 45, 68 (1958)

101. Bean, E. L., Advances in Chem. Ser., 21, 430 (1959)

102. Chambers, C. W., and Proctor, C. M., R. A. Taft Sanitary Eng. Center, Tech. Rept. W60-4, 18 pp. (1960)

103. Wuhrmann, K., and Zobrist, F., Schweiz. Z. Hydrol., 20, 218 (1958) 